destroyed every green thing. The plague lasted for weeks, and until the insects obtained wings, when the winds soon after wafted them away to devastate the lower country, and the ocean received them. Any opposition seemed so hopeless that none was attempted."

Among the most terrible of the insect scourges which affect the vast territories of the Western World, is the army-worm. The name arouses old associations, and one involuntarily recalls " the canker-worm, and the caterpillar, and the palmer-worm, my great army which I send among you." The army-worm well deserves his name, although like most familiar vernacular appellations it may have been wrongly employed. The cotton-worm (Aletia xylina), for example, has been so designated; but the true army-worm is Leucania unipuncta, known in the earlier chronicle as the "black worm," and is the larva of a Noctuid moth, named as above by Haworth. It is difficult to give an idea of the fearful character of this plague when in obedience to solar influence it begins its march. "Almost with a shudder (p. I45) one remembers that terrible invasion of Monmouth, when the potato fields were ruined as if by fire, and the waggon wheels reeked with green dripping gore as they entered our villages. ... That beautiful lawn of Hollywood at Long Branch was invaded by them. The emerald sward was swept as if burnt. When any of the worms came against a tree they went up it, passed over the crotch, then descended at the other side. There is no 'turn back' to this singular worm, and when their path is intercepted by a stream, on they come, until, crowded forward, a compacted mass is urged into the water to serve as a living pontoon, over which the army passes to take possession of pastures new."

Another account states that the army-worm when travelling will scarcely turn aside for anything but water, and even shallow water-courses will not always change its progress. They avoid the rays of the sun, hence during the day they crawl under stones and sticks as closely as they can crowd themselves together, like the cut-worm. They come out towards sunset and continue their mighty march. If they come to a field of grass or young grain they devour the whole of it, down to the very roots; but if it is grown up to stalks they eat the leaves only, and then usually crawl to the top of the stalk and cut off the head and drop it to the ground.

They all keep together like an army of soldiers, and usually advance in a straight line, not swerving from their course to avoid hills, hollows, buildings, or any other obstacle. On coming to a brook, they crowd into it; millions of them are drowned, their dead bodies clogging and damming up the stream in places below, producing by their decay a stench in the atmosphere of the whole vicinity most noisome and intolerable.

Monmouth County was invaded in 1880 , and the following graphic sentences from the New York Sun will help us to obtain an idea of this calamity :-

"Trenches were seen extending for miles along the roads close to the edges of the fields, but the crops for the most part were withered and lifeless, and it was evident that the precautions had been taken too late. Very often a trench ran across a wheat-field, showing where the farmer had abandoned one portion of his crops and tried to save the remainder. Occasionally a field was seen intersected by numerous trenches, indicating that the proprietor had fought manfully against his persecutors, and disputed the ground with them foot by foot. In many places the road was literally covered with the worms, all in motion, and all moving towards the fields on either side. Thousands and tens of thousands were crushed beneath the waggon wheels and under the horses' feet, but the rest passed on. And at intervals spots were passed where an imaginary line seemed to be drawn across the road beyond which the army-worms could not pass. For a certain space beyond, sometimes for a distance of two or three miles, not only the roads, but the adjoining country was free from the pest. Not a worm was to be seen until, the clear space passed, the waggon was again rolling over millions of them." The remedies suggested partake of the general character of the means proposed by entomologists, and are probably mostly learnt by the entomologists from the farmers and peasants. They consist in rolling, fencing, ditching, burning, coal-tarring, poisoning, "drawing the rope," which is done by two men drawing the rope in a direction at right angles to its own length.

Another pest of different habits and less widespread destructiveness is the Canker-worm (Anisopteryx pometaria and oscularia), an insect which feeds on the leaves of apple-trees, and completely ruins orchards. Entomological science has conferred a boon by suggesting methods of getting rid of this creature by taking advantage of its peculiarities. The female, like our glowworm, is wingless, and therefore cannot rapidly spread beyond the locality where it exists. She hibernates in the earth near the roots of trees, and on the first return of spring she ascends the trunk, depositing her eggs between the leaflets of the expanding buds, sometimes even close to the ground, but oftenest under loose scales of bark. It is this peculiarity of the female which enables the fruitgrower to grapple with the difficulty. One of the best means is what is known as "hanging the band." This contrivance consists essentially of a band or ring of tin a few inches outside the trunk of the tree, and held there by a circle of muslin attached to the tin at its edge, and drawn with a cord at the top, so as to fit the tree closely and prevent the insects from going over the tin, which is coated with a mixture of castor-oil and kerosene : as soon as they touch this they drop to the ground. Troughs of oil arranged closely around the tree, or the complete isolation of the tree by fitted boarding lined on the outside by smooth tin and also fitted with shallow troughs for oil are also used. Another ingenious plan is to use a cylinder of sheet tin upon a band of line or cord. The cord forms a firm boss around the tree, and the hollow cylinder surrounds it and extends them at four inches above and below it. The female finds this an effective barrier, and it is said if she even succeeds in passing upwards to the top of the cylinder she will never descend in the inside so as to again reach the tree.

A good deal of interesting evidence is adduced upon the effects of "jarring and burning," or the jarring of the affected trees, after spreading a light coating of dry straw on the ground bclow, which is then fired without injury to the trees. A table-spoonful of Paris-green in twelve quarts of water applied to the tree with a large syringe, when, as nearly as can be judged, the worms are all hatched, is a second method. "Fall-ploughing" is a third plan, which appears to have been very successful; and, lastly, attention has been very properly drawn to the balance of power in nature by encouraging birds and parasitic insects that live upon the canker-worm. A valuable distinction has also been pointed out by the Commission between the "fall" canker-worm, and the spring species, from which it differs in many important respects, as may be gathered from its name. There are many other interesting chapters in the volume which we should have liked to at least have mentioned, but it is not our object to do more than give a good general idea as to the work of the Commission and the manner in which it is prosecuted. We therefore leave the consideration of the Hessian fly and the Rocky Mountain cricket, 'with a hearty recommendation to those who are interested in economic entomology to obtain this Report.

J. W.

\section{THE FORESTRY EXHIBITION}

I last week's NATURE (p. 222) we briefly noticed the remarks of the Marquess of Lothian in declaring the International Forestry Exhibition at Edinburgh open. For 
several reasons it has not been in the power of some foreign Governments to be represented at the Exhibition. And in more than one case, notably that of Chili, an unforeseen accident occurred to prevent others who intended to be present. Where direct participation, in so far as exhibits are concerned, has been impossible, official maps and publications bearing on the forest service or literature of the country have been forwarded, or a representative has been commissioned officially to attend, or the efforts of private individuals have been exerted to supply the omission. The Exhibition has thus been inaugurated by the co-operation of many of the foreign and colonial Governments, and by the good wishes of all.

In the arrangement of the articles exhibited the geographical principle has been adopted, the goods of each country being together.

A scientific arrangement was very desirable, and the "classification" issued by the Executive Committee was prepared with that intention, but it was found impossible to arrange the Catalogue in accordance with it, from the imperfect details given in many of the schedules of exhibitors, and the tardy arrival of the consignments. Great latitude has been allowed to the admission of goods, which have been largely received during the week since the opening, and we believe that the very large and interesting collection from Japan will be in its place in a few days.

The Catalogue contains much valuable information, especially the portion relating to India and the Scottish Arboricultural Society, which together cover eighty pages; but it is not yet complete with respect to several colonies and foreign Governments, notably Japan. A new edition is promised, more easy of reference, where the theoretical classification of the articles on paper will agree with the actual distribution in the building.

The ground on which the buildings are erected is 5 acres in extent. The main building is 650 feet long by 55 feet broad, with three annexes, each 150 feet long by 55 feet broad, with a high central dome in each annexe.

The design of the buildings is similar to the main galleries in the Health Exhibition, Kensington. Additional annexes, 500 feet long and 25 feet broad, similar in design to the main buildings, were erected at a later stage in consequence of the large demands for space by the Japanese Government, \&c.; the exhibiting area thus became one-third larger than its original extent. It is a handsome light building which produces a very agreeable effect on entrance.

The Electric Railway runs along two sides of the building, and is about 650 yards in length. On the west side of Donaldson's Hospital grounds a field 7 acres in extent was inclosed for the purpose of exhibiting woodworking machinery in motion, nurserymen's exhibits, greenhouses, iron houses, wire fencing, gates, \&c. Here will be found various huts and châlets, including one from Balmoral; also the Manitoba Settler's Farm, and many varieties of models of gates, fencing materials, \&c., exhibited by the Commissioner of Her Majesty's Woods and Forests, all having a connection with the wide subject of forestry.

The Indian collection occupies the south central transept, and several bays on each side; it is very large and interesting; the catalogue has a historical preface by Sir George Birdwood. The arrangement is admirable, Col Michael and his assistant having had experience in the Paris, Vienna, and Amsterdam Exhibitions.

The Index Collection of Timbers sent by the Government of India, comprises 800 specimens, with their commercial uses and habitats, and illustrates arboreal vegetation from Thibet to Cape Comorin; each specimen is carefully labelled.

In the Indian Court may be specially noticed the very valuable series of maps and diagrams executed by the Forest Survey Department under Major Bailey, R.E.. who has himself arranged them in an instructive manner. The excellence of these topographical surveys can scarcely be overrated in connection with the demarcation and management of the reserved forests divided into blocks or compartments, and in the case of boundary disputes their value is undeniable. For students of forestry this is a most important feature of the Exhibition, and shows the silent progress of the great work which has been carried on by Dr. Brandon and his assistants during the past twenty-five years.

The only other country which exhibits maps showing in detail the general distribution of forests is Denmark. There are three sheets displaying the occurrence of the forests of conifers and of broad-leaved trees, also the extent of newly-planted areas and the geological formations on which they grow. There are also maps of the forest district of Kronborg which resemble those made in Germany, and are very neatly executed.

It would have been very desirable that sets of these illustrative maps had been furnished as far as possible by various Governments to assist in determining the rates of growth of indigenous trees in different countries. For instance these diagrams give the mean height from 20 to I 20 years, and show that in Germany the height of beech and spruce is greater than in Denmark; but the average diameter of the latter exceeds that of the former.

In the Indian collection an interesting contribution from Col. Yule has found a temporary resting place. Marco Polo, who tells us of the existence of the roc, a bird of wonderful dimensions, further tells how the feather or quill of the roc was brought back by envoys to Madagascar or East Africa, and presented to the Great Khan. Col. Yule and Sir John Kirk seem now to have brought to light the true roc's quill in the frond of the leaf of the Raphia palm, which is largely used on the coast near Zanzibar for making stages, ladders, rafters, and doors. The hard ligneous frond, stripped of its leaflets, somewhat resembles a stripped feather; the largest is twentyfive feet four inches long, and twelve inches in girth at the base.

\section{TECHNICAL SCHOOL EDUCATION AT THE HEALTH EXHIBITION ${ }^{1}$}

$\mathrm{I} \mathrm{N}$ last week's issue some account was given of the appliances, methods, and results of primary school education to be seen at the Health Exhibition, and we ventured to express the hope that this remarkable and probably unprecedented collection would be carefully inspected by as many as possible of our schoolmasters and mistresses, as well as by school managers and others. In the present article it is proposed to deal similarly with technical handicrafts and science teaching as practised not merely in England, but in those foreign countries and organisations which, as previously stated, have brought together such excellent collective exhibits.

The increased attention now being devoted to the whole subject of infant training, and the enlarged sympathy and interest with which the best modern teachers are studying the methods of Fröbel (some of the developments of which are at the basis of all so-called technical training), have justified the appropriation of a considerable space to illustrations of the Kindergarten system. The British and Foreign School Society have devoted the whole of the room at their disposal to this purpose, in order to make the display as complete as possible, and here will be found a practical answer to those who allege that "Kindergarten work is all play," for the manner in which it leads up to various trades is distinctly shown. In the Belgian Court there is also a very complete and effective Kindergarten exhibit, though it contains nothing specially new, and the

$$
\text { I Contirusd from p. } 2 \text { <0 }
$$

